\title{
THE ROLE AND RESPONSIBILITY OF STAKEHOLDERS IN THE PLANNING PROCESS OF THE SUSTAINABLE URBAN MOBILITY IN THE CITY KRAKOW
}

\begin{abstract}
This article presents the process of identifying and selecting stakeholders, whose role and position is important to achieve the overall goals of planning sustainable urban mobility in the Municipality of Krakow. The authors identified possible conflicts and coalitions between stakeholders and illustrated how this could affect the development of the planning process in the context of the geographical area, integration between strategic planning documents, availability of resources and general validity.
\end{abstract}

Keywords: transport planning, mobility, SUMP

\section{Introduction}

Transport planning is often a controversial area where decisions are widely commented and require, in the light of political democratization, social acceptance. Involvement of stakeholders and citizens may legitimize decisions and, in addition, lead to new, innovative management models that try to balance different positions and interests. Participation in planning processes reflects the general integration of citizens and groups in decision-making processes, and thus participation in authority.

The term commonly used, in the context of participation is a "stakeholder", who may be a natural person, group or organization that is affected by the proposed project or which may have an impact on the project and its implementation ${ }^{1}$. These

1 A. Fung, Participation, Deliberation, and Representation in the Policy Process. Civic Engagement in the $21^{\text {st }}$ Century, University of Southern California, October 1-2, 2004. 
groups generally cover public opinion as well as a wide range of other groups (e.g. enterprises, public authorities and interest groups). In transport planning, different groups of stakeholders may be subject to considerable influence. The rigorous limitation of their routine transport behaviour ${ }^{2}$ will affect their daily operations.

\section{Identification of stakeholders}

In order to find appropriate ways to deal with dominant or weak stakeholders and those dealing with intermediate positions, according to the guidelines of the handbook ${ }^{3}$ three main groups of stakeholders were distinguished depending on the specific position they occupy in the decision-making process:

- basic stakeholders: Who will ultimately be affected (positively or negatively) by new transport activities (for example: on residents within various social or professional groups, individual city districts, business sectors, individual entities)?

- strategic stakeholders: Who is the political responsibility (presidents, mayors, councilors, other levels of government)? Who has financial resources (public and private funds)? Who exercises power (in a given sphere or territory)? Who has the skills and knowledge (public administration, universities, private sector) in the field of transport and related fields (land use, environmental protection, education, health, tourism, etc.)?

- intermediaries: Who implements the transport policy (operators of public transport and infrastructure, public administration, police, etc.)? Who implements the main transport activities (suppliers of goods, ports, airports, etc.)? Who represents important interest groups (associations, chambers of commerce, cooperatives, networks)? Who carries out information activities and reports on transport (authorities, operators, local media)?

In a more specific approach to the GUIDEMAPS ${ }^{4}$ project handbook, seven main groups can be classified:

- local government authorities - actions will be initiated by local or regional authorities due to the competences and availability of human and financial resources;

- residents - as the final recipients of the results of the conducted policy of managing mobility, in individual groups of people using public transport, drivers, cyclists and pedestrians;

- enterprises operating on the local market - due to the possibility of increasing their development potential related to better accessibility for customers and better operating conditions on the market;

K. Hebel, M. Wolek, Perception of modes of public transport compared to travel behaviour of urban inhabitants in light of marketing research, Scientific Journals. Transport/Silesian University of Technology 2016, 92.

3 Ibidem.

4 GUIDEMAPS - Gaining Understanding of Improved Decision Making and Participation Strategies, European ( $5^{\text {th }}$ RTD Framework Programme). 
- local transport operators - effective implementation of Plan for Sustainable Urban Mobility will increase the attractiveness of public transport as the main subsystem contributing to the balancing of the entire transport system;

- carriers of goods, delivery and logistics companies;

- non-governmental organizations - in particular those working for sustainable transport, associations of cyclists, pro-ecological foundations, organizations working for people with reduced mobility, for pedestrians, etc.;

- other entities (e.g. cultural institutions, sports and recreation centers, providing educational services, schools, colleges, business incubators, etc.).

After identifying the stakeholders, their mutual relations were analyzed. The analysis was based on the list of four criteria concerning: interest in the process of planning sustainable urban mobility and the level of influence on the decisions made in this process. The aim of a systematic analysis of relations between stakeholders is to get a clear picture of conflicts of interest or potential coalitions and to identify a group of stakeholders who can show different levels of participation, opportunities and interest in a given issue.

The process of mapping stakeholders in the influence-interest matrix, which aims to group stakeholders based on the level of impact and/or significance, is presented in Table 1 and 2.

Table 1. Matrix INFLUENCE vs. INTEREST

\begin{tabular}{|l|l|l|}
\cline { 2 - 3 } \multicolumn{1}{c|}{} & \multicolumn{1}{c|}{ Low level of influence } & \multicolumn{1}{c|}{ High level of influence } \\
\hline Little interest & $\begin{array}{l}\text { A group of stakeholders } \\
\text { with the lowest impact }\end{array}$ & $\begin{array}{l}\text { Useful for formulating opinions } \\
\text { and decisions }\end{array}$ \\
\hline Big interest & $\begin{array}{l}\text { An important group } \\
\text { of stakeholders, may require } \\
\text { increased rights }\end{array}$ & $\begin{array}{l}\text { The most critical group } \\
\text { of stakeholders }\end{array}$ \\
\hline
\end{tabular}

Source: GUIDELINES - Developing and Implementing a Sustainable Urban Mobility Plan - Rupprecht Consult - Forschung und Beratung GmbH, Eltis 2014

Table 2. List of all potential stakeholders in the matrix INFLUENCE vs. INTEREST matrix for the city of Krakow

\begin{tabular}{|l|l|l|}
\cline { 2 - 3 } \multicolumn{1}{c|}{} & \multicolumn{1}{c|}{ Low level of influence } & \multicolumn{1}{c|}{ High level of influence } \\
\hline \multirow{2}{*}{} & City Secretary & $\begin{array}{l}\text { Miejskie Przedsiębiorstwo Komunikacyjne } \\
\text { S.A. w Krakowie }\end{array}$ \\
\cline { 2 - 3 } & Treasurer of the City & Mobilis sp z o.o. \\
\cline { 2 - 3 } & Research institutes & Local media \\
\cline { 2 - 3 } & The operator of the city bike system - Wavelo & Main employers \\
\cline { 2 - 3 } & Car-sharing operator - Traficar & People with limited mobility \\
\cline { 2 - 3 } & Primary and secondary schools & Parents and children \\
\cline { 2 - 3 } & Urban media & Elderly people \\
\cline { 2 - 3 } & $\begin{array}{l}\text { Provincial Inspector for Environmental } \\
\text { Protection }\end{array}$ & Bus operators \\
\hline
\end{tabular}


Table 2. cont.

\begin{tabular}{|c|c|c|}
\hline & Low level of influence & High level of influence \\
\hline \multirow{6}{*}{ 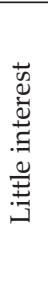 } & Domestic non-governmental organizations & Krakow Balice Airport \\
\hline & PKP Przewozy Regionalne & Residents of neighboring communes \\
\hline & Kraków Nowa Huta Przyszłości S.A. & Polish State Railways \\
\hline & Police Headquarters in Krakow & Universities - public and private \\
\hline & Municipal Police of Krakow & $\begin{array}{l}\text { Authorities of neighboring communes, } \\
\text { commune of the Krakow poviat }\end{array}$ \\
\hline & Polish Motor Union & Local companies \\
\hline \multirow{13}{*}{ 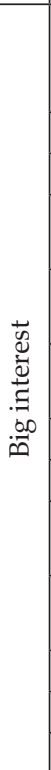 } & Miejska Infrastruktura sp. z.o.o. & $\begin{array}{l}\text { The Mayor of the City of Krakow } \\
\text { and the Deputy, Plenipotentiaries } \\
\text { and Advisors of PMK }\end{array}$ \\
\hline & Foundations and associations & Residents of Krakow \\
\hline & Tourists - domestic and foreign & City Hall of Krakow \\
\hline & Krakowski Park Technologiczny sp. z o.o. & $\begin{array}{l}\text { The Management of Municipal Infrastructure } \\
\text { and Transport in Krakow }\end{array}$ \\
\hline & $\begin{array}{l}\text { Project managers at UMK as part } \\
\text { of the Project Management System }\end{array}$ & City Council of Krakow \\
\hline & $\begin{array}{l}\text { Research and development centers } \\
\text { of companies }\end{array}$ & Krakowski Holding Komunalny \\
\hline & Technology Transfer Centers & Trasa Łagiewnicka S.A. \\
\hline & Local business incubators & City Development Agency \\
\hline & $\begin{array}{l}\text { Association of Engineers and Technicians } \\
\text { of Communication of the Republic of Poland }\end{array}$ & Boards and District Councils I-XVIII \\
\hline & $\begin{array}{l}\text { Marshal's Office of the Lesser Poland } \\
\text { Voivodship }\end{array}$ & Municipal Investment Management \\
\hline & Lesser Poland Voivodship Office & - \\
\hline & Ministry of Infrastructure & - \\
\hline & Ministry of Development & - \\
\hline
\end{tabular}

Source: own elaboration

In Table 2, the stakeholders are grouped due to their potential level of influence on the planning process and the degree of interest in participating in this process. The key are the stakeholders representing a high level of influence and a lot of interest. They should have the greatest potential to influence the shape of the Sustainable Urban Mobility Plan, and in many cases they will provide the acceptable infrastructural and organizational solutions acceptable in the document.

\section{Strategic stakeholders}

The process of adopting and then implementing the Sustainable Urban Mobility Plan requires broad acceptance at the political level, which in Krakow is tantamount to the resolution of the controlling body and constituting the Municipality of Krakow - the City Council of Krakow. The adoption and implementation of Sustainable Urban Mobility Plan requires taking action to influence the councilors in order to obtain the approval of the majority of the forty-three members of the City Council of Krakow. 
Actions taken towards local governments should rely on the use of strategies and operational techniques based, among others, on marketing, based on rational, facts supported arguments presented by adopted action plan.

According to W. Ofman ${ }^{5}$, the effectiveness of the actions taken does not only depend on positive relations with decision-makers, but depends on the ability to choose the right strategy for communicating arguments. As there is no closed catalog of techniques and tools to influence representatives of municipal government, new instruments are constantly emerging, which were characterized in Table 3, developed on the basis of a publication dedicated to issues of public relations in the opinion-forming process ${ }^{6}$.

Direct actions consisting in a traditional form at bilateral meetings are the most effective form of influence on decision-makers. In turn, indirect actions focus on shaping public opinion in order to obtain its support in the first place ${ }^{7}$. Indirect activities will require the City Hall to engage in its so-called third party, which may be media or NGOs and associations supporting the idea of adopting the Sustainable Urban Mobility Plan.

Table 3. Catalog of activities of influencing the representatives of the municipal government

\begin{tabular}{|c|c|c|}
\hline \multicolumn{2}{|c|}{ Direct actions } & \multirow{2}{*}{ Indirect actions } \\
\hline Personal & Written & \\
\hline $\begin{array}{l}\text { - meetings } \\
\text { - discussions } \\
\text { - } \text { press conferences } \\
\text { - } \text { parties } \\
\text { - } \text { public speeches } \\
\text { - } \text { prsentations } \\
\text { - visits } \\
\text { - discussions in committees } \\
\text { - networking }\end{array}$ & $\begin{array}{ll}\text { - } & \text { letters } \\
\text { - } & \text { e-mails } \\
\text { - } & \text { studies } \\
\text { - } & \text { statistical data } \\
\text { - } & \text { articles } \\
\text { - } & \text { booklets } \\
\text { - } & \text { books } \\
\text { - } & \text { posts in social media }\end{array}$ & 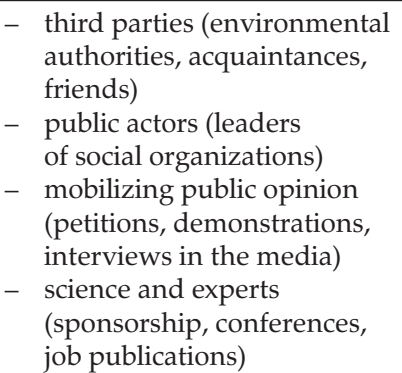 \\
\hline
\end{tabular}

Source: own elaboration

It will be of great importance to refer to current social campaigns in the area of environmental and health protection that allow to emphasize the group context of the issue and to obtain an atmosphere conducive to the adoption of a resolution regarding the Sustainable Urban Mobility Plan.

The effectiveness of actions taken against politicians requires tact, diplomacy and sensitivity to social engineering aspects. For ethical reasons, you should not use blackmail or exchange benefits, however, each time a decision on how to approach a particular group of local government officials should be preceded by a cost-benefit analysis.

N. Ofmański, Public affairs and lobbying [in:] Sztuka public relations. Z doświadczeń polskich praktyków, ed. B. Janiszewska, Związek Firm Public Relations, Warsaw 2011, p. 281.

6 S. Kuśmierski, Public relations $w$ procesie opiniotwórczym, WSE, Warsaw 2006, p. 47

7 M. Molęda-Zdziech, Od lobbingu klasycznego ku cyberlobbingowi. Grupy interesu i lobbing. Polskie doświadczenia w unijnym kontekście, IFiS PAN, Warsaw 2011, p. 179-180. 
Taking into account the above-mentioned conditions concerning methods of exerting influence on local government representatives in the context of the city of Krakow, direct meetings of representatives of the city authorities with Councilors are recommended in order to present arguments for the admission of the Sustainable Urban Mobility Plan. In discussions, emphasis should be placed on the effects of the adoption of the Sustainable Urban Mobility Plan, such as the improvement of air quality and the reduction of road congestion, which have recently become very important.

\section{The division of roles and the scope of responsibility of stakeholders}

In the table, divided into 4 different groups (in terms of direct impact on the planning process), the main stakeholders of the process were compiled, bearing in mind their role in shaping sustainable mobility policy - from initiators/decision makers, through observers to final recipients of services resulting from decisions taken.

Table 4. List of potential stakeholders in the context of the division of roles and responsibilities

\begin{tabular}{|c|c|c|}
\hline No. & Entity/Group & The role and scope of the stakeholder's responsibility \\
\hline \multicolumn{3}{|r|}{ Authority/Board } \\
\hline 1 & $\begin{array}{l}\text { The Mayor of the City of Krakow } \\
\text { and the Deputy, Plenipotentiaries } \\
\text { and Advisors of PMK }\end{array}$ & $\begin{array}{l}\text { Main initiators of the Sustainable Urban Mobility Plan } \\
\text { process, political responsibility }\end{array}$ \\
\hline 2 & City Secretary & Coordination of arrangements with selected entities \\
\hline 3 & Treasurer of the City & $\begin{array}{l}\text { Financial plan of the Sustainable Urban Mobility Plan, } \\
\text { budget of individual activities }\end{array}$ \\
\hline 4 & $\begin{array}{l}\text { Krakow City Hall - selected } \\
\text { departments }\end{array}$ & $\begin{array}{l}\text { Department - responsible for the development } \\
\text { and consultation of the Sustainable Urban Mobility } \\
\text { Plan as a whole, other departments - substantive input, } \\
\text { arrangements, etc. }\end{array}$ \\
\hline 5 & City Council of Krakow & $\begin{array}{l}\text { The main political body accepting the document } \\
\text { at the political level through the resolution of City } \\
\text { Council }\end{array}$ \\
\hline 6 & $\begin{array}{l}\text { Boards and District Councils } \\
\text { I-XVIII }\end{array}$ & Participants of the arrangements at the local/district level \\
\hline 7 & $\begin{array}{l}\text { Authorities of neighboring } \\
\text { communes, commune } \\
\text { of the Krakow poviat }\end{array}$ & $\begin{array}{l}\text { Participants of the arrangements at the level } \\
\text { of the functional area of Krakow }\end{array}$ \\
\hline 8 & $\begin{array}{l}\text { The Management of Municipal } \\
\text { Infrastructure and Transport } \\
\text { in Krakow }\end{array}$ & $\begin{array}{l}\text { Implementer of majority of the implementation activities } \\
\text { assumed in Sustainable Urban Mobility Plan }\end{array}$ \\
\hline 9 & $\begin{array}{l}\text { Municipal Investment } \\
\text { Management }\end{array}$ & $\begin{array}{l}\text { Implementer of majority of the implementation activities } \\
\text { assumed in Sustainable Urban Mobility Plan }\end{array}$ \\
\hline 10 & Miejska Infrastruktura sp. z.o.o. & $\begin{array}{l}\text { Implementer of some of the implementation activities } \\
\text { assumed in Sustainable Urban Mobility Plan }\end{array}$ \\
\hline
\end{tabular}




\begin{tabular}{|c|c|c|}
\hline No. & Entity/Group & The role and scope of the stakeholder's responsibility \\
\hline 11 & Trasa Łagiewnicka S.A. & $\begin{array}{l}\text { Implementer of some of the implementation activities } \\
\text { assumed in Sustainable Urban Mobility Plan }\end{array}$ \\
\hline 12 & Krakowski Holding Komunalny & Participant of arrangements at the local level \\
\hline 13 & City Development Agency & Participant of arrangements at the local level \\
\hline 14 & Police Headquarters in Krakow & $\begin{array}{l}\text { Participant of arrangements at the local level, responsible } \\
\text { in the selected area for monitoring the effects } \\
\text { of Sustainable Urban Mobility Plan implementation }\end{array}$ \\
\hline 15 & Municipal Police of Krakow & $\begin{array}{l}\text { Participant of arrangements at the local level, responsible } \\
\text { in the selected area for monitoring the effects } \\
\text { of Sustainable Urban Mobility Plan implementation }\end{array}$ \\
\hline 16 & $\begin{array}{l}\text { Project managers at UMK as part } \\
\text { of the Project Management Syst }\end{array}$ & $\begin{array}{l}\text { Participants of arrangements at the local level (e.g. } \\
\text { organizational and IT issues) }\end{array}$ \\
\hline 17 & $\begin{array}{l}\text { Marshal's Office of the Lesser } \\
\text { Poland Voivodship }\end{array}$ & Participant of arrangements at the regional level \\
\hline 18 & Lesser Poland Voivodship Office & Participant of arrangements at the regional level \\
\hline 19 & $\begin{array}{l}\text { Ministry of Transport } \\
\text { and Construction }\end{array}$ & $\begin{array}{l}\text { The participant of the arrangements at the national level } \\
\text { provides the framework and guidelines for the plans } \\
\text { at the regional/urban level }\end{array}$ \\
\hline 20 & Ministry of Development & $\begin{array}{l}\text { The participant of the arrangements at the national level } \\
\text { provides the framework and guidelines for the plans } \\
\text { at the regional/urban level }\end{array}$ \\
\hline \multicolumn{3}{|c|}{ Companies/Operators } \\
\hline 1 & $\begin{array}{l}\text { Miejskie Przedsiębiorstwo } \\
\text { Komunikacyjne S.A. w Krakowie }\end{array}$ & Participant of arrangements at the local level \\
\hline 2 & Mobilis sp z o.o. & Participant of arrangements at the local level \\
\hline 3 & Bus operators & Participant of arrangements at the local level \\
\hline 4 & Krakow Balice Airport & Participant of arrangements at the local level \\
\hline 5 & Car-sharing Operator - Traficar & The role of the observer and provider of selected services \\
\hline 6 & $\begin{array}{l}\text { The operator of the city bike } \\
\text { system - Wavelo }\end{array}$ & The role of the observer and provider of selected services \\
\hline 7 & Main employers & The role of the observer and provider of selected services \\
\hline 8 & Local companies & The role of the observer and provider of selected services \\
\hline 9 & Polish State Railways & Participant of arrangements at the local level \\
\hline 10 & PKP Przewozy Regionalne & Participant of arrangements at the local level \\
\hline \multicolumn{3}{|r|}{ Local communities } \\
\hline 1 & Residents of Krakow & $\begin{array}{l}\text { Participants of arrangements at the local level, key } \\
\text { recipients of Sustainable Urban Mobility Plan products }\end{array}$ \\
\hline 2 & Local media & The role of the observer and provider of selected services \\
\hline 3 & Municipal media & The role of the observer and provider of selected services \\
\hline 4 & Polish Motor Union & The role of the observer and provider of selected services \\
\hline 5 & Tourists - domestic and foreign & $\begin{array}{l}\text { Key recipients of the Sustainable Urban Mobility Plan } \\
\text { products }\end{array}$ \\
\hline 6 & $\begin{array}{l}\text { Residents of neighboring } \\
\text { communes }\end{array}$ & $\begin{array}{l}\text { Key recipients of the Sustainable Urban Mobility Plan } \\
\text { products }\end{array}$ \\
\hline 7 & Parent and children & $\begin{array}{l}\text { Key recipients of the Sustainable Urban Mobility Plan } \\
\text { products }\end{array}$ \\
\hline 8 & Elderly people & $\begin{array}{l}\text { Key recipients of the Sustainable Urban Mobility Plan } \\
\text { products }\end{array}$ \\
\hline
\end{tabular}


Table 4. cont.

\begin{tabular}{|c|c|c|}
\hline No. & Entity/Group & The role and scope of the stakeholder's responsibility \\
\hline 9 & People with limited mobility & $\begin{array}{l}\text { Key recipients of the Sustainable Urban Mobility Plan } \\
\text { products }\end{array}$ \\
\hline \multicolumn{3}{|r|}{ Other } \\
\hline 1 & Universities - public and private & The role of the observer and provider of selected services \\
\hline 2 & Research institutes & The role of the observer and provider of selected services \\
\hline 3 & $\begin{array}{l}\text { Provincial Inspector for } \\
\text { Environmental Protection }\end{array}$ & Participant of arrangements at the local level \\
\hline 4 & Primary and secondary schools & The role of the observer and provider of selected services \\
\hline 5 & $\begin{array}{l}\text { Association of Engineers } \\
\text { and Technicians } \\
\text { of Communication } \\
\text { of the Republic of Poland }\end{array}$ & Participant of arrangements at the local level \\
\hline 6 & Foundations & Participant of arrangements at the local level \\
\hline 7 & Foundations and associations & Participant of arrangements at the local level \\
\hline 8 & $\begin{array}{l}\text { Krakowski Park Technologiczny } \\
\text { sp. z o.o. }\end{array}$ & The role of the observer and provider of selected services \\
\hline 9 & $\begin{array}{l}\text { Kraków Nowa Huta Przyszłości } \\
\text { S.A. }\end{array}$ & The role of the observer and provider of selected services \\
\hline 10 & $\begin{array}{l}\text { Research and development } \\
\text { centers of companies }\end{array}$ & The role of the observer and provider of selected services \\
\hline 11 & Technology Transfer Centers & The role of the observer and provider of selected services \\
\hline 12 & Local business incubators & The role of the observer and provider of selected services \\
\hline 13 & $\begin{array}{l}\text { Domestic non-governmental } \\
\text { organizations }\end{array}$ & The role of the observer \\
\hline
\end{tabular}

Source: own elaboration

\section{Conclusions}

Examples of transport planning in Europe, where controversial urban development projects have led to mass protests show that planning processes without public legitimacy can be blocked and, in the worst case, even abandoned. Such cases also show that the rejection of intentions by society initiated a broad discussion about planning. The idea of sustainable urban mobility should encourage local governments, institutions and organizations to go beyond their own borders and responsibilities in order to ensure consistency and complementarity with strategies in related sectors (transport, spatial planning and land use, health, energy, municipal services, education, security of public order and safety, etc.). Such coordination is a major challenge for planning sustainable urban mobility, but it is also the main source for implementing innovation and improvement of planning processes. 


\section{References}

Arnstein S.R., A Ladder of Citizen Participation, Journal of the American Planning. Association 1969, 35(4).

Downar W., System transportowy: kształtowanie wartości dla interesariusza, Rozprawy i Studia. University of Szczecin 2006, 624(316).

Fung A., Participation, Deliberation, and Representation in the Policy Process. Civic Engagement in the $21^{\text {st }}$ Century, University of Southern California, October 1-2, 2004.

Górniak J., Kołdras S., Mazur S., Paszkowska R., Communication and social participation Guidebook, Cracow 1999.

GUIDELINES - Developing and Implementing a Sustainable Urban Mobility Plan Rupprecht Consult - Forschung und Beratung GmbH (Cologne, Germany), developed under the project ELTISPLUS, contract no. EACI/IEE/2009/05/S12.558822.

Hebel K., Wolek M., Perception of modes of public transport compared to travel behaviour of urban inhabitants in light of marketing research, Scientific Journals. Transport/Silesian University of Technology 2016, 92.

Kuśmierski S., Public relations w procesie opiniotwórczym, Związek Firm Public Relations, Warsaw 2006.

Molęda-Zdziech M., Od lobbingu klasycznego ku cyberlobbingowi. Grupy interesu i lobbing. Polskie doświadczenia w unijnym kontekście, IFiS PAN, Warsaw 2011.

Ofmański N., Public affairs and lobbying [in:] Sztuka public relations. Z doświadczeń polskich praktyków, WSE, Warsaw 2011.

\section{Corresponding authors}

Maciej Michnej can be contacted at: maciej.michnej@mech.pk.edu.pl

Tomasz Zwoliński can be contacted at: tomasz.zwolinski@um.krakow.pl 